\title{
The Renaissance of Insurgency and Counter-Insurgency: Examining Twenty-First Century Insurgencies and Government Responses
}

\author{
John J. Le Beau*
}

\begin{abstract}
Insurgency and counterinsurgency as types of warfare are currently subject to considerable attention due to the nature of the high-profile struggles underway in Afghanistan and Iraq. It is prudent to note that neither insurgency nor the strategy and tactics required to combat it represent new phenomena. A large body of experience and literature from the twentieth century and earlier exists that addresses both sides of the insurgent struggle. Some characteristics of insurgencies are largely immutable, since insurgency is ultimately a form of warfare that is adopted when a combatant has limited resources and limited choices for how to fight against a more powerful adversary. Today as in the past, these characteristics include employment of small-unit attacks, ambushes, assassinations, propaganda activity, and the development of covert infrastructure. Nevertheless, the primary insurgencies active in the twenty-first century are marked by important differences from earlier struggles, particularly in the areas of motivation and inspiration. Rather than being quintessentially political and interested in local or national grievances, many contemporary insurgencies are at their core linked to a particular interpretation of Islam. Thus, these insurgencies represent a war of religion, not of politics, economics, or ethnicity. Islamist insurgencies are likely to be uncompromising and averse to negotiation, absolutist and pan-national in their goals, and willing to justify the mass slaughter of non-combatants who do not share their religious vision.

Counterinsurgent strategies that take into account the religious world-view of their opponents are better equipped for success than counterinsurgent efforts that ignore or minimize the radical Islamist dimensions of the struggle. Saudi Arabia offers an example of a counterinsurgency campaign that has been tailored to deal with an Islamist challenge. Modern communications and technology may link disparate Islamist insurgencies to some degree, and might eventually provide a means of coordination and information sharing. In fact, this may already be occurring. Contests with Islamist insurgencies around the globe are likely to continue for a protracted period.
\end{abstract}

Keywords: insurgency, counterinsurgency, Islamist, Jihadist, Islam, terrorism, Al-Qaeda, unconventional warfare, Osama bin Laden, Ayman al-Zawahiri, Saudi Arabia.

Dr. John J. Le Beau is a former United States intelligence senior operations officer and chair of the Partnership for Peace Consortium Combating Terrorism Working Group. He is also a Marshall Center Professor regularly active in the Program on Terrorism and Security Studies. 
What has been will be again, what has been done will be done again; there is nothing new under the sun. Even the thing of which we say, 'See, this is new!' has already existed in the ages that preceded us. Ecclesiastes 1:9-10 ${ }^{1}$

\section{Introduction}

The phenomenon of insurgency and its riposte in the form of counterinsurgency surely provide exemplary validation of that biblical injunction. While it was a salient and muchdebated theme in military and political establishment circles in the 1980 s, interest in insurgency as a form of unconventional warfare waned rapidly once the major powers' focus on the Cold War proxy struggles in El Salvador, Nicaragua, Afghanistan, and Angola withered and eventually ceased altogether. By the end of the Cold War at the latest, military and political thinkers, commentators, and experts moved on to consider types of violence other than the now dethroned and disregarded "low intensity conflict" (LIC), one of the acronymic aliases under which insurgency had been studied. Insurgency became passé for the military thinker - not venerable enough to elicit the attention of the true historian, not recent enough to engage the contemporary commentator seeking relevance. But now, at the onset of the twenty-first century, events have come around full circle with the high-profile, protracted unconventional warfare in Afghanistan and Iraq.

Insurgency and counterinsurgency are back in the headlines and at the center of thinktank discussions, even if the predominant venues of conflict are different from those of twenty years ago. Since 2004, the situation in Iraq has developed into what is indisputably an insurgency, with both rural and urban dimensions and with U.S. and Coalition forces belatedly adopting counterinsurgency tactics that would certainly be familiar to Sir Robert Thompson (1916-92) and other respected counter-terrorist specialists of the 1980s. ${ }^{2}$ In what should be a striking example of déjà vu, Afghanistan represents another insurgent battleground, with Western forces roughly in the position of the Soviet army in the 1980s, and with some of the same individuals on the insurgent side having been participants in both struggles, decades apart. Less heralded in terms of press coverage and international interest but nonetheless worthy of note are the ongoing conflicts in southern Thailand and in the Philippines, with Somalia and perhaps Algeria thrown in for good measure. It is also arguable that early-stage insurgencies, nascent and fragile as they may be, are currently underway in Morocco, Yemen, and perhaps other locations.

What seems indisputable is that the ideological progenitor of many contemporary insurgencies is fundamentally different from the force that spurred the major insurgent struggles of the 1970s, 1980s, and earlier periods of the twentieth century. Absent in the cases of Afghanistan, Iraq, Somalia, and Thailand, for instance, are generally leftist or Marxist roots or motivations. Indeed, from today's vantage point, the socialist justifications, vocabulary, and world-view common to many earlier insurgencies appear irredeemably anachronistic. At its core, however, what has changed in this century are not so much insurgent strategies and tactics (although there have of course been innovations in

New Catholic Edition of the Holy Bible (New York: Catholic Book Company, 1962), 737.

2 See Sir Robert Thompson, Revolutionary War in World Strategy, 1945-1969 (New York: Taplinger Publishing Company, 1970). 
these areas as well, driven in part by technological advances), but the ideas that impel the insurgents to violent action in the first instance. Common and critical to several contemporary twenty-first century insurgencies is the phenomenon of radical, political Islam. The theoreticians and practitioners of the struggles in Afghanistan, Iraq and Somalia employ a logic and lexicon that is undeniably Koranic in its spirit and inspiration. Indeed, participants in many contemporary insurgencies, from foot soldiers to senior strategists, describe their activity as jihad, a type of divinely sanctioned struggle described in the Koran, commented on and attested to in the hadith, and enjoying pride of place in the long march of the history of warfare in the Muslim world. ${ }^{3}$ We will examine this factor of contemporary insurgency in some detail and assess what this implies for counterinsurgent forces.

\section{Insurgency: What Remains the Same}

Reference to respected works analyzing insurgency and counterinsurgency reveals that many historical characteristics of this form of struggle remain basically the same today as they were in the past. Various principles of the insurgent contest, on examination, appear to be as true in the twenty-first century as they were in the twentieth, or even much earlier. Often heard in the 1980s, for example, was the mantra (of uncertain provenance) that insurgency represented "the war of the weak against the strong." This phrase could perhaps be said to be the genesis of the more recent concept of "asymmetric warfare." Insurgents choose the tactics that they do precisely because those are the tactics that are available to them. Insurgencies are generally formations of those who, though not completely powerless, possess less conventional power and resources than states. Accordingly, the tactics and activities employed by, say, the FMLN in El Salvador are not, in many respects, so different from the insurgent activities currently underway in Afghanistan or Somalia. Attacks on rural police stations, small military patrols, and individual government officials are common occurrences in all of these conflicts. Similarly, the insurgent today, as in the past, prefers to be an elusive enemy, adept at avoiding superior government forces and able, in many instances at least, to blend into the general population.

We are often reminded, quite appropriately, that counterinsurgency is not purely a military struggle. Neither is insurgency. Both sides of the equation have political or ideological aims and attempt to win uncommitted adherents to their respective position. Accordingly, conveying a message to the public is of no mean importance. Since they are often deprived of the sophisticated communications apparatus enjoyed by nation-states, insurgent movements have historically developed their own alternate means of reaching a target audience by harnessing the technology available to them at the time. During the twentieth century, insurgent radio stations gained an avid listenership - and considerable international publicity - in Algeria, Cuba, and El Salvador, to name only a few zones of conflict. Government forces in these and other countries with active insurgencies sought to shut down these "rebel" transmitters (which were often quite primitive but relatively mo-

3 Patrick Sookhdeo, Global Jihad (McLean, VA: Isaac Publishing, 2007), 140: "The practical rules of jihad are laid down in the source texts and in the classical legal texts of Islam. As we have seen, Muhammed himself and his companions serve as examples of how to practice jihad, models to be emulated by the umma." 
bile), usually without notable or lasting success. Some of these clandestine stations acquired a mystique precisely because of their ability to frustrate government efforts to put them out of business. Similarly, contemporary Islamist insurgencies enthusiastically employ the Internet and video downloads to promote their message, providing the interested with a visual as well as an aural message. Indeed, a 2007 research study concluded that there are approximately 5,600 $\mathrm{Al}$ Qaeda-linked web sites active at present, providing Islamist insurgents and terrorists with a significant international propaganda reach. ${ }^{4}$

Another aspect of insurgencies that has not changed much over the decades is what we might term the "texture" of such campaigns. Now as then, insurgencies seek to obtain and employ small arms and quantities of conventional explosives for their attacks. Where possible, insurgents today attempt to employ foreign safe havens for protection (the Turkish PKK in Northern Iraq, Afghan Taliban insurgents in the Pakistan tribal areas), as did earlier insurgent groups (Vietnamese in the Cambodian border area, Nicaraguan Contras using encampments in Honduras). Many insurgencies in both this century and the previous one have established a covert infrastructure of safe houses, explosive assembly sites, and rudimentary hospitals as well as organizations engaged in fund-raising, document forging, bomb production, communications, intelligence gathering, and like activities. This subterranean texture of insurgent movements provides something like an invisible world existing just below the surface of the existing state that the insurgency is committed to overthrowing.

In sum, the fabric of current insurgencies has much in common with the insurgencies of the past. This proposition can be readily demonstrated by applying the principles of the U.S. government-produced Guide to the Analysis of Insurgency, written in the 1980s, to any number of insurgencies active today. ${ }^{5}$ The core characteristics of insurgencies enumerated in that publication over twenty years ago remain equally valid today. But if there is much about insurgent and counter-insurgent conflict that has not changed, it must also be said that the ideological foundation of contemporary insurgencies is very different from the past indeed, a topic to which we now turn.

\section{Insurgency in the Twenty-First Century: What is New}

A survey of current, ongoing insurgencies indicates that the most deadly conflicts of an insurgent nature - measured variously by levels of casualties, damage, and degree of international interest - are struggles being conducted by groups identifying themselves as $j i$ hadist or salafist. That is, the framework and justification of the resort to violence by these groups is firmly and unambiguously anchored in a particular interpretation of Islam. Indeed, a case can be made that a number of these insurgencies do not see themselves as discrete armed movements operating against a single nation-state or regime to right local grievances and install alternate polices, but rather as part of a broadly international, religiously-based war against those they identify as anti-Islamic. The sheer number of these

4 Ibithal Hassan, "Al Qaeda-linked Web sites number 5,600: Researcher," reuters.com (4 December 2007).

5 Central Intelligence Agency, Guide to the Analysis of Insurgency (Washington, D.C., Government Printing Office, undated). 
Koranically-inspired groups suggests that they are likely to dominate the insurgent stage for the next several years and possibly decades. The distinction between Islamist-based insurgencies and other types of campaigns is neither trivial nor without troubling implications, which we will now explore.

First, a cautionary word on vocabulary is required. Much discussion has revolved around the appropriate term to employ regarding Muslim groups that engage in terrorist activity and, by extension for the purposes of this article, insurgency campaigns. It is indisputably true that the word jihad has meanings within the Islamic tradition that are nonviolent and refer to an inner, spiritual struggle. It is also the case that the word jihad, even when understood to signal violence, does not literally translate into "holy war." As a result, it has been asserted in some quarters that the word jihadist is not appropriate to describe the likes of, say, Osama bin Laden or his followers. Similar objections have been raised in various fora against use of the term salafist, although some terrorists and insurgents apply this term to themselves. More importantly, perhaps, many Muslims bristle at Westerners making reference to "Islamic terrorists" or even "Islamist terrorists," on the grounds that such terminology implies a link between violent practices and one of the world's great religions. Nonetheless, since a particular interpretation of Islam is clearly at the very heart of the motivation of people such as Osama bin Laden and Ayman Muhammed al-Zawahiri, and it is logically impossible to escape some sort of association of this particular religious tradition with groups such as Al Qaeda, the former GSPC, Jemaah Islamiyah, and similar violent movements. This article employs the term Islamist (despite its imperfections) to cover insurgencies and terrorist groups that justify their deeds on the basis of a form of Islam that impels its adherents into ideological action rather than theological reflection. The term Islamist insurgency as used in this article refers to those insurgent movements whose motivation - as measured by their public statements - is primarily based on the canon of Islam: the Koran, hadith, and the traditions of Muhammed.

\section{Contemporary Insurgencies}

Islamist insurgencies active today are geographically widespread and include those in Afghanistan, Somalia, southern Thailand, the Philippines, and Algeria at an absolute minimum. In addition, possible early-stage or incipient Islamist insurgencies might be considered to include Yemen, Saudi Arabia, Morocco, Lebanon, and even the United Kingdom. As with many historical insurgencies in their formative stages, some of these violent challenges to authority will be effectively crushed out of existence before they can pose a more serious or sustained threat to government forces. This may be the case in Saudi Arabia, where police and intelligence organizations have over the past two years enjoyed singular success in disrupting planned terrorist activities (including strikes on oil facilities) and in killing and capturing a large number of individual Al Qaeda-linked operatives engaged in a campaign of violence against the House of Saud. ${ }^{6}$ Saudi government success aside, other incipient insurgencies can be expected to flourish in the absence of more effective government counter-measures.

6 Peter Bergen, "Saudi 200 held over 'terror plots," CNN.com (28 November 2007). 
The observant reader will note that Iraq is absent from the above list of Islamist insurgencies, despite the fact that a major insurgency is clearly being waged there against Coalition and Iraqi forces. The complexities observable in the case of Iraq require elaboration. Reporting from the conflict strongly indicates that Iraq represents something more than simply an Islamist insurgency. To be sure, highly organized and deadly Islamist elements, perhaps most notably Al Qaeda in Iraq, are playing an important role in the current rural and urban insurgency in that country; these groups have succeeded in attracting the lion's share of international media attention. Nonetheless, non-Islamist elements are playing important roles in challenging Iraqi stability as well. These include former Baath Party members and their supporters, who have primarily secular motivations, as well as criminal elements (organized and individual), which seek personal gain and opportunistic profit from violent acts against the government, its foreign allies, and the Iraqi populace in general. Ancient ethnic hostilities play a role as well, as do sectarian enmities that do not precisely translate into Islamist motivation or ideology. Accordingly, it is probably judicious to place Iraq in something of a special, separate category while acknowledging that elements of an Islamist insurgency are visible there, mixed into a maelstrom of violence that has many authors. Any mention of Iraq in the following pages will refer solely to aspects of the insurgency that are clearly Islamist according to our definition.

\section{Islamist Insurgency: Motivation and Goals}

At the broadest level and based on their own public statements, Islamist insurgencies aim to achieve the return of an Islamic Caliphate incorporating Muslim-majority lands and, in some cases at least, also including territory that was once under Muslim rule but was subsequently lost to non-Muslim forces. This would include Israel as well as Spain (part of the Umayyad Caliphate in the sixth century) and substantial parts of the Balkans. Another commonly shared goal of Islamist insurgencies is the broad application of a severe form of Sharia law in areas under insurgent control. This goal was achieved in Taliban-controlled Afghanistan prior to the United States invasion of that country in late 2001, and is, according to various accounts, the state of affairs prevailing today in the tribal areas of Pakistan where Islamist insurgents operate without notable interference from the central government.

Another feature of Islamist insurgency bears mentioning here. As the statements of various Islamist spokesmen (there are, of course, no real Islamist spokeswomen) make clear, Islamist adherents (along with many practitioners of "mainstream" Islam) accept the notion that the world is divided between the Dar-al-Islam, or the "house of Islam," and the Dar-al-Harb, or "house of war."7 That is, the Islamist Weltanschauung is inherently conflictual, dividing the world into Islamic countries and non-Islamic countries. As the vocabulary indicates, Islamists view it as fully appropriate and laudatory to conduct violence against non-believer states. This view of the world as a religious battlefield - with the commensurate literal demonization of the enemy-informs the everyday life of the Islamist insurgent, and certainly enhances Islamist groups' absolutist tendencies and their

7 Sookhdeo, Global Jihad, 481. 
unwillingness to compromise. In effect, we should expect that this viewpoint will make any meaningful negotiations with Islamist insurgents difficult (if not futile) from the outset.

The Islamist insurgent goals posited above are, to be sure, inherently more sweeping than the local or national goals sought by any number of non-Islamist insurgencies historically, such as earlier struggles in Malaysia, Vietnam, and Angola, to cite a few. Although religiously inspired Islamist goals are arguably more visionary than strategic in nature, and may be judged unlikely to be achieved, broad goals are certainly not unknown in insurgent movements. One need only recall the pan-national "revolutionary" vision espoused by Ernesto "Che" Guevara and others who aimed to establish one form or another of utopian Marxian ideals and transnational Communist rule. ${ }^{8}$ Visionary goals, even if seen as chimerical by those not embracing them, can nonetheless be a powerful motivating force for an insurgency, whether it is structured on traditional lines or according to the newer Islamist model. That said, contemporary Islamist insurgencies appear to be shaped to a great degree and in considerable detail by an interpretation of Koranic injunction, and in this respect differ notably from the template of past insurgencies. Indeed, the record suggests that the Islamist mindset and goals have affected the manner in which Islamists wage their own brand of insurgency.

\section{Waging Insurgency as Jihad}

What are the characteristics of Islamist insurgency that differ importantly from the characteristics traditionally attributed to insurgencies? Measured in terms of strategy and tactics, what distinguishes, say, Al Qaeda in the Maghreb from the FARC in Colombia? Several traits of Islamist insurgent campaigns can arguably be identified, and are common to a number of Islamist insurgencies internationally.

First, Islamist insurgents do not see the core of their struggle as primarily political, but rather as primarily religious. The establishment of a new, powerful Caliphate is indeed a political goal (no matter how fanciful), but it is predicated on a religious imperative to extend the borders of the Dar-al-Islam. Importantly, virtually all Islamist insurgents and terrorists perceive themselves as engaged in jihad, a just and violent struggle sanctioned by Islam. There is no credible evidence whatsoever suggesting that Islamist leaders are cynically employing religion as a vehicle to attain power or wealth - what they say is what they believe.

Second, Islamist insurgent strategists are heavily influenced in their thinking by the traditions of the Prophet, the Koran, and other elements of the Muslim canon, and they frequently refer to these sources in their public comments. Accordingly, religious thought and notions have a real and direct impact on shaping the content and conduct of Islamist insurgent activity.

8 Che Guevara offered many aphorisms related to "international revolutionary solidarity." Note for example: "There are no boundaries in this struggle to the death. We cannot be indifferent to what happens anywhere in the world, for a victory by any country over imperialism is our victory; just as any country's defeat is a defeat for all of us." "Che Quotes," geocities.com; accessed 5 January 2008 . 
Third, when reduced to its lowest common denominator, the strategic goal of Islamist insurgency is to extend the rule of Islam while reducing the autonomy of unbelievers. While Islamist insurgents may well have a national focus (Algerian Islamists are most directly concerned about replacing the regime in Algeria, for example, or Egyptian Islamists with overthrowing the rule of Hosni Mubarak), at the same time they perceive themselves as engaged in a struggle transcending national borders. This again underlines the fact that the motive force behind Islamist insurgency is not basically national in nature, or even political as commonly understood in the West, but religious. ${ }^{9}$ It is noteworthy, for example, that Ayman Al-Zawahiri (who certainly considers himself a strategist) in his various audio and video recordings has urged adherents to action in locations as geographically far flung as Saudi Arabia, Sudan, Somalia, Pakistan, and Europe. Seen through the prism of the Islamist insurgent leaders and venerated figures, the insurgency is truly global in nature, with several fronts in operation.

Fourth, tactics and practices in Islamist insurgency can themselves be based on religious grounds and precedents. For example, attacks carried out by Islamist groups in which Muslims are killed have to be justified in a manner that casts the perpetrators as defenders of the faith, rather than as offenders against it. The same applies to the tactic of suicide bombing, which Islamists readily justify although suicide per se is contrary to the belief system of Islam. ${ }^{10}$ Justification of specific Islamist insurgent tactics is often accomplished through sometimes labored and obscurantist theological reasoning. Also illustrative is the use of beheading as a means of executing captives that have been identified as unbelievers or apostates (again, the religious resonance of the vocabulary is notable). Beheading was a common form of execution during the lifetime of Muhammed, and there are references to it in Islamic texts. This form of killing, doubtless intended by its authors to intimidate, has been widely practiced (and often filmed) by Islamist insurgents in Afghanistan, Iraq, Thailand, the Philippines, Saudi Arabia, and elsewhere. ${ }^{11}$

Fifth, distinct from past insurgencies, Islamist insurgencies and the terror organizations to which they are linked have demonstrated that they are at best indifferent to civilian casualties and frequently purposefully target civilian populations with the goal of inflicting mass casualties. Statistical analysis of the number of civilian casualties inflicted by terrorists globally indicates an upward trajectory from the 1970s through 2003: "The sharp rise

9 Bernard Lewis, The Crisis of Islam (New York: Random House, 2004), 6: "The dichotomy of regnum and sacerdotium, so crucial in the history of Western Christendom, had no equivalent in Islam. During Muhammed's lifetime, the Muslims became at once a political and a religious community, with the Prophet as head of state."

10 Suicide bombing is not a tactic used solely by Islamist insurgents or terror networks; secular Palestinian organizations and non-Muslim Sri Lankan insurgents have employed this (often effective) weapon as well. Nonetheless, suicide bombings aimed at causing large numbers of civilian casualties have become a signature of Islamists. The perpetrator is referred to as a Shahid, or martyr. For an empirically-based study on suicide bombing see Robert A. Pape, Dying to Win (New York: Random House, 2005).

11 In addition to Islamist websites, graphic videos of beheadings have been posted to www.liveleak.com and other mainstream sites. It merits mention that nearly all such videos are accompanied by martial music and quotations from the Koran. 
in casualties corresponds to the emergence of Islamist terrorism."12 Masses of civilians have routinely been the intended victims of Islamist attacks in Algeria, Thailand, Great Britain, Pakistan, Tunisia, Egypt, and elsewhere (most notably the United States). The Islamist elements of the Iraqi insurgency, specifically Al Qaeda in Iraq, have been widely regarded as the most egregious killers of civilians in that conflict, responsible for some of the worst high-casualty bombings in Baghdad and elsewhere. In contrast, Salvadoran insurgents in the 1980s, Cuban Fidelista insurgents in the 1950s, and Sri Lankan Tamil Tiger (LTTE) adherents over the last decades have demonstrably favored military and police targets over purely civilian ones. It should be noted that the Al Qaeda attacks on the United States on 11 September 2001 represent the first historical instance where mass civilian casualties reached into the thousands.

Finally, Islamist insurgencies have demonstrated a willingness to employ modern technology to serve a cause that might otherwise be characterized as medieval in many respects. Use of the Internet for propagandizing, covert communications, and recruitment of new adherents is a case in point. Similarly, Islamist forces have exhibited a clear interest in harnessing modern technology to provide them with striking power beyond that provided by mere conventional explosives. Al Qaeda experimentation with the nerve agent Sarin in Afghanistan is an example of this, as is the kitchen laboratory work with Ricin attributed to an Islamist cell in the United Kingdom. It is certainly within the realm of possibility that Islamists will overcome practical difficulties and employ a chemical or even biological weapon against an adversary in the coming years. ${ }^{13}$

Taken as a whole, the above characteristics of Islamist insurgency suggest that the twenty-first century is likely to witness a number of protracted violent struggles pitting Islamist movements against various "apostate" nation-states, and that the core objection to the rule of those nation-states will be on religious grounds. To be properly understood, Islamist insurgencies (and the terror organizations related to them) need to be understood as fundamentally wars of religion; this feature importantly distinguishes Islamist insurgencies from past insurgencies that inhabited a political world. Contemporary Islamist insurgencies will be (as they have been to date) uncompromising in seeking to achieve their goals. A hallmark of Islamist insurgency will continue to be a definition of the "enemy" in broad terms, encompassing "infidel" civilians as well as members of the military and security forces. This attitude in turn permits the wholesale slaughter of non-combatants to be justified in terms of a transcendent moral duty. In addition, Islamist forces operating independently in Thailand, Algeria, Afghanistan, Pakistan, and countries in the West will perceive themselves to be united by an overarching religious cause, and motivated by the desire to see the eventual triumph of Sharia over temporal, political rule. Modern communications will permit geographically distant insurgencies to feel somehow united, and may eventually develop into a means of coordinating diverse groups and individuals.

12 Robert S. Leiken, "Europe's Mujahideen - Where Mass Immigration Meets Global Terrorism," cis.org (April 2005), 5.

13 Nick Robertson, "Disturbing Scenes of Death Show Capability with Chemical Gas," CNN.com (19 August 2002). 


\section{Counterinsurgency in the Twenty-First Century}

Counterinsurgency strategies and tactics employed against ongoing Islamist challenges to established authority vary from country to country, as one might expect. In the cases of Afghanistan and Iraq, Western forces (primarily but not solely represented by the United States) are playing a critical role both in devising and implementing a counterinsurgency formula, with the host governments cast in a secondary (although by no means inconsiderable) role. As noted previously, Iraq represents more than simply an Islamist insurgency, but the counterinsurgency effort there has devoted considerable attention specifically to reducing the inroads made by Islamist forces. In the case of Somalia in 2007, Ethiopian troops (along with occasional and limited military action by the United States) have been the most active element operating against the Islamic Courts Union's urban and rural insurgency. These instances aside, the counterinsurgency responses to Islamist violence in Algeria, Thailand, Pakistan, Saudi Arabia, and the Philippines have been predominantly national affairs. Although none of the insurgencies in these countries have to date been decisively defeated, some counterinsurgencies have clearly enjoyed more measurable success than others. Available information provides some grounds for believing that the most successful counterinsurgency efforts against Islamist forces today are those that focus their attention and tailor their actions not just to the challenges posed by generic insurgency, but to the phenomenon of violent Islamism specifically.

Saudi Arabia has been faced with an incipient insurgency since at least 2001. Islamist militants associated with $\mathrm{Al}$ Qaeda have been responsible for a series of attacks (both actual and planned) in the Kingdom, some of them exhibiting significant boldness and lethality. Targets have included official Saudi installations, foreign guest compounds and diplomatic buildings, individual foreigners and, notably, oil industry facilities. At first, Saudi authorities seem to have largely ignored or studiously minimized the extent of the problem. This official Saudi attitude calls to mind Sir Robert Thompson's succinct but trenchant commentary on early-stage insurgency. He observed that governments confronting a budding insurgency often delude themselves into not recognizing that they are facing an armed challenge to their authority; "This automatically leads to a situation where government countermeasures are too little, too late until the time comes when really drastic action has to be taken." 14

Over time, however, the Saudi authorities appear to have concluded that the Islamists indeed posed a major security threat to the ruling regime and resolved to crush the insurgency. Although information currently in the public domain remains sketchy, Saudi efforts in some respects mirror successful counterinsurgency measures from past conflicts, including Malaysia. Specifically, the Saudis eschewed a mainly military approach to the Islamist challenge, and concentrated instead on police and intelligence activity directed against Al Qaeda adherents. This doubtless entailed suborning and recruiting local sources of information, the collection of intelligence on cell member identities, leadership hierarchy, covert infrastructure, funding and logistical support to the Islamists, and other pieces of detailed information that could be exploited. To the extent that can be judged based on partial information, Saudi security forces seem to have conducted their activities without

14 Thompson, Revolutionary War, 21. 
alienating the general population, another traditional characteristic of a successful counterinsurgency. Hundreds of arrests have been made to date, some involving violent confrontations, but it would appear that the government has not resorted to the ill-conceived and overly broad "sweeps" that net the innocent along with the guilty and ultimately damage government legitimacy.

The Saudi strategy against the Islamists has additionally incorporated measures specifically tailored to defeat the message and appeal of Islamist propaganda, both with the general Saudi public and within the ranks of captured insurgents. Saudi clerics have been used to delegitimize violent Islamist claims that they are forwarding the interests of Islam and that they are operating within the boundaries of permissible Muslim behavior. The case of the former radical Saudi cleric Sheikh Salman al-Odah is illustrative. Imprisoned in Saudi Arabia between 1994 and 1999 for his radical activities, al-Odah, often described as a "mentor" of Osama bin Laden, in 2007 publicly denounced Al Qaeda-related violence in Saudi Arabia, Afghanistan, and elsewhere on religious grounds. ${ }^{15}$ This measure and similar measures endorsed or orchestrated by Saudi authorities, of course, are predicated on a recognition that the core of the threat to official Saudi interests rests mainly on religious grounds. Similarly, as has been widely reported, the Saudi government has established a formal "deprogramming" effort that aims to persuade captured Islamist activists that they have chosen a wrong path that is incompatible with true Islam. The mainstay of this program is an intensive and focused attempt at dialogue between prisoners and imams or Islamic scholars, with the end goal of persuading the Islamist detainees to reject their violent doctrine and former comrades and to reintegrate into mainstream Saudi (and Wahhabi Sunni) society. ${ }^{16}$

At this stage it is too early to attempt to assess the effectiveness of the Saudi counterinsurgency efforts described above. Nonetheless, the Saudi methods noted are notable for the theological nature of their focus, and are tailored to meet the special demands of Islamist twenty-first century insurgency. It is also noteworthy that Saudi Arabia is not alone in attempting to address the particularly Islamist nature of the insurgent and terrorist threat. Indonesia, faced with its own flare-ups of Islamist violence, including the deadly and highly publicized Bali bombings in 2002 , has initiated a similar program as well. ${ }^{17}$ It can in fact be argued that Muslim-majority countries might well understand the core nature of the challenge to their rule more clearly than their Western counterparts, who downplay the religious dimensions of many contemporary insurgent movements. This attitude arguably plays a role in the manner in which the United States has directly and indirectly confronted insurgencies overseas (in Afghanistan, Pakistan, and Somalia, for example), and the manner in which the United Kingdom has confronted Islamist attacks on its own soil, in London and Glasgow. While perhaps quite understandable in the context of secular democratic institutions and prevailing political conditions, there certainly exists the risk that

15 Fawaz A. Gerges, “Osama bin Laden's Growing Anxiety," Christian Science Monitor (26 October 2007). See also Hassna'a Mokhtar, "Bin Laden's Mentor a Reformed Man,” arabnews.com (6 January 2008).

16 Jennifer Griffen, "Saudi Youth Enter Rehab to Overcome their Terrorist Ways," foxnews.com (22 August, 2007).

17 Joshua Kurlantzick, "Fighting Terrorism with Terrorists," latimes.com (6 January 2008). 
not understanding the makeup and message of an insurgency poorly equips a government to craft an effective response to it. If the ideological core and appeal of an insurgency are not acknowledged, it is hard to imagine that a suitable counter-message strategy can be launched.

On a more general level, and aside from the issue of confronting the Islamist insurgent message, it can be safely projected that counterinsurgency efforts in the twenty-first century will be concerned with attacking Islamist insurgent foes in some ways that are quite similar to counterinsurgency methodologies devised and employed in the previous two hundred years. With a glance at some current insurgencies, some of these methods can be suggested; the below list is by no means meant to be comprehensive.

- Deny domestic and foreign safe haven to insurgent forces. The safe haven issue in the twentieth century included the examples of Nicaraguan Contra camps in Honduras and Vietnamese use of Cambodian territory. At present, denying safe haven areas to insurgents is directly applicable to counterinsurgency efforts in Afghanistan, Pakistan, Saudi Arabia, Lebanon, and elsewhere.

- Limit insurgent access to weapons and explosives. The proliferation and dissemination of knowledge about explosives production on the Internet (and perhaps via Afghan and Iraqi insurgent veterans) makes this a formidable task for counterinsurgency forces in several countries, including those that might be facing an incipient or potential insurgency, such as the United Kingdom and France.

- Break insurgent military organizations and incapacitate leadership elements. This is the military side of counterinsurgency, and is being conducted along traditional counterinsurgency lines in Afghanistan, the Philippines, Somalia, Iraq, and perhaps Lebanon (against Fatah-al-Islam forces).

- Provide adequate security for the populace and demonstrate government "presence" and the physical limitations of insurgent power. This translates into denying the insurgents the ability to claim that "the government rules by day, we rule by night," and similar formulations. The methods devised by French colonial officers and strategists Bugeaud, Gallieni, and Lyautey, generally classified as tache d'huile, are applicable here. ${ }^{18}$ The difficult task of providing the civilian populace with some measure of security is a key goal in counterinsurgency efforts underway in Afghanistan, and represents a considerable weakness in the counterinsurgencies in Pakistan (especially in the tribal areas) and in Southern Thailand.

- Deny the insurgents foreign support. In the twentieth century, this generally referred to denying the insurgents covert or overt support from states sympathetic to their cause. This historical list is extensive and includes Castroite Cuban support for various Latin American violent movements, Nicaraguan support for the Salvadoran FMLN, clandestine U.S. support for Jonas Savimbi’s UNITA in Angola, North Vietnamese support for the Viet Cong, etc. Foreign support in the context of present-day Islamist insurgencies, however, may mean something substantially different - the provision of person-

18 Francis Toase, "The French Experience," in The Roots of Counter-Insurgency, ed. Ian F.W. Beckett (London: Blandford Press, 1988), 40-59. 
nel, finances, and wherewithal not from a nation-state but from the international Islamist movement and its sympathizers. Accordingly, we witness the phrase "foreign fighter" applied to insurgents in Afghanistan and Iraq who originate from Saudi Arabia, Libya, or Muslim diaspora populations in Europe (including Italy and the United Kingdom). While some Islamist insurgencies have undoubtedly enjoyed state support (an accusation persuasively made by the United States regarding Iran and Syria), insurgent ranks in several conflicts have been strengthened by committed Islamist adherents from several nations, sharing the common bond of religious belief and interpretation. Mosques and Islamic cultural centers have often served as recruiting grounds.

\section{Conclusion}

The renaissance of insurgency and counterinsurgency in this century contains elements that are familiar from the historical record as well as elements that are new and innovative. A notably wide array of current insurgencies are at their heart Islamist insurgencies, motivated less by political grievances or ideological considerations as commonly understood than by a sternly theological viewpoint that recognizes no boundary between religion and politics and that makes absolutist and transcendent claims to legitimacy and authority. The crucial role of Islam (at least a particular type of Islam) in these insurgencies is recognized by some counterinsurgency strategies (e.g., Saudi Arabia) and perhaps not by others (e.g., the United States' efforts). The Internet, mobile communications, international travel, and globalization may facilitate an increasing sense of unity among separate Islamist insurgencies. This, in turn, could under the right circumstances develop into a coordinated transnational threat to international security concerns; indeed, this might already be happening. As in the past, successful counterinsurgent responses will rely on the adoption of an appropriate array of methods to confront a protracted security threat, only some of these methods military. Even tried and true counterinsurgency methods, however, will need to adapt to the special challenges of a dedicated Islamist insurgency seeking to operate without frontiers to achieve ambitious, transnational goals. 
SPRING 2008

\section{Bibliography}

Griffen, Jennifer. Saudi Youth Enter Rehab to Overcome their Terrorist Ways. foxnews.com , 2007.

Kurlantzick, Joshua. Fighting Terrorism with Terrorists., 2008.

Lewis, Bernard. The Crisis of Islam . New York: Random House, 2004.

Pape, Robert A.. Dying to Win: The Strategic Logic of Suicide Terrorism . New York: Random House, 2005.

Robertson, Nick. Disturbing Scenes of Death Show Capability with Chemical Gas. 19 August 2002, 2002.

Sookhdeo, Patrick. Global Jihad . McLean, VA: Isaac Publishing, 2007.

Thompson, Robert. Revolutionary War in World Strategy, 1945-1969 . New York: Taplinger Publishing Company, 1970.

Toase, Francis. The French Experience In The Roots of Counter-Insurgency. London: Blandford Press, 1988. 